\title{
The optimal dose of rocuronium for rapid sequence induction
}

\author{
Mohammad El-Orbany, MD · Mursel Antapli, MD
}

Received: 7 August 2009/Accepted: 24 August 2009/Published online: 25 September 2009

(C) Canadian Anesthesiologists' Society 2009

\section{To the Editor,}

In their study using lidocaine, low-dose rocuronium, remifentanil, and propofol for tracheal intubation, SiddikSayyid et al. ${ }^{1}$ found tracheal intubation conditions $90 \mathrm{sec}$ after rocuronium $0.3 \mathrm{mg} \cdot \mathrm{kg}^{-1}$ to be comparable to those achieved $60 \mathrm{sec}$ following succinylcholine $1.5 \mathrm{mg} \cdot \mathrm{kg}^{-1}$. The onset of neuromuscular block is a function of the dose given. Using electromyography, the onset of rocuronium $0.6 \mathrm{mg} \cdot \mathrm{kg}^{-1}$ at the laryngeal adductors was found to be $106 \mathrm{sec}$ in one study and $124 \mathrm{sec}$ in another. ${ }^{2,3}$ The onset of lower doses is further delayed and can be too slow for rapid sequence induction purposes. ${ }^{4}$ Higher doses $\left(1 \mathrm{mg} \cdot \mathrm{kg}^{-1}\right)$ are recommended when rapid tracheal intubation is indicated. ${ }^{5}$ Low doses will also result in a less intense block at the laryngeal adductors, which are known to be more resistant than skeletal muscles to the action of rocuronium. ${ }^{6}$ Using a $0.25 \mathrm{mg} \cdot \mathrm{kg}^{-1}$ dose, Meistelman et al. found the maximum block attained at the vocal cords to be only $37 \pm 8 \%$. $^{7}$ Thus, low doses may only result in a delayed and partial laryngeal block. The authors' favourable results are due to their strict adherence to the described induction technique. As pointed out in the accompanying editorial, minor deviations from that technique may lead to different results, including failure to achieve tracheal intubation due to poor relaxation and inadequate intubation conditions. ${ }^{8}$ This may increase the risk of aspiration during the rapid sequence induction which the technique was originally instituted to guard against. The authors are to be commended for describing a technique that can be advantageous for brief surgical procedures that require muscle relaxation. A Cochrane

M. El-Orbany, MD $(\varangle) \cdot$ M. Antapli, MD

Medical College of Wisconsin, Milwaukee, WI, USA

e-mail: elorbany2000@yahoo.com database review, however, showed that the optimal dose of rocuronium for rapid sequence induction probably should be higher than $1 \mathrm{mg} \cdot \mathrm{kg}^{-1}$.

Competing interests None declared.

\section{References}

1. Siddik-Sayyid SM, Taha SK, Kanazi GE, et al.. Excellent intubating conditions with remifentanil-propofol and either low dose rocuronium or succinylcholine. Can J Anesth 2009; 56: 483-8.

2. Hemmerling TM, Schmidt J, Wolf T, Klein P, Jacobi K. Comparison of succinylcholine with two doses of rocuronium using a new method of monitoring neuromuscular block at the laryngeal muscles by surface laryngeal electromyography. $\mathrm{Br} \mathrm{J}$ Anaesth 2000; 85: 251-5.

3. Dhonneur $G$, Kirov $K$, Slavov $V$, Duvaldestin $P$. Effects of an intubating dose of succinylcholine and rocuronium on the larynx and diaphragm: an electromyographic study in humans. Anesthesiology 1999; 90: 951-5.

4. Schlaich N, Mertzlufft F, Soltesz S, Fuchs-Buder T. Remifentanil and propofol without muscle relaxants or with different doses of rocuronium for tracheal intubation in outpatient anaesthesia. Acta Anaesthesiol Scand 2000; 44: 720-6.

5. Andrews JI, Kumar N, van den Brom RH, Olkkola KT, Roest GJ, Wright $P M$. A large simple randomized trial of rocuronium versus succinylcholine in rapid-sequence induction of anaesthesia along with propofol. Acta Anaesthesiol Scand 1999; 43: 4-8.

6. Wright PM, Caldwell JE, Miller RD. Onset and duration of rocuronium and succinylcholine at the adductor pollicis and laryngeal muscles in anesthetized humans. Anesthesiology 1994; 81: $1110-5$.

7. Meistelman C, Plaud B, Donati F. Rocuronium (ORG 9426) neuromuscular blockade at the adductor muscles of the larynx and adductor pollicis in humans. Can J Anaesth 1992; 39: 665-9.

8. Kopman AF. How low can you go? Lowest effective dose of neuromuscular blocking agent for tracheal intubation. Can $\mathrm{J}$ Anesth 2009; 56: 473-7.

9. Perry JJ, Lee JS, Sillberg VA, Wells GA. Rocuronium versus succinylcholine for rapid sequence induction intubation. Cochrane Database Syst Rev 2008; CD002788. 